\title{
Comparative Evaluation of Farmers' Perception and Adaptation Strategies to Climate Change and Variability in Bako Tibe, Ethiopia and Abeokuta, Nigeria
}

\author{
Chizoba Obianuju Oranu', Anthonia Ifeyinwa Achike1, Amanuel Zenebe², \\ Abadi Teklehaimanot ${ }^{3}$ \\ ${ }^{1}$ Department of Agricultural Economics, University of Nigeria, Nsukka, Nigeria \\ ${ }^{2}$ Institute of Climate and Society, Mekelle University, Mekelle, Ethiopia \\ ${ }^{3}$ Department of Agriculture Extension, Mekelle University, Mekelle, Ethiopia \\ Email: chizoba.oranu@unn.edu.ng, ifyachike@gmail.com, amanuelzenebe@gmail.com, abatekle@gmail.com
}

How to cite this paper: Oranu, C.O., Achike, A.I., Zenebe, A. and Teklehaimanot, A. (2018) Comparative Evaluation of Farmers' Perception and Adaptation Strategies to Climate Change and Variability in Bako Tibe, Ethiopia and Abeokuta, Nigeria. American Journal of Climate Change, 7 , 611-623.

https://doi.org/10.4236/ajcc.2018.74038

Received: September 18, 2018

Accepted: December 11, 2018

Published: December 14, 2018

Copyright $(9) 2018$ by authors and Scientific Research Publishing Inc. This work is licensed under the Creative Commons Attribution International License (CC BY 4.0).

http://creativecommons.org/licenses/by/4.0/

\section{(c) (i) Open Access}

\begin{abstract}
Comparing the perception of farmers to climate change and variability in Bako Tibe, Ethiopia and Abeokuta, Nigeria is important in promoting sustainable agriculture and in understanding the impact of climate change and variability on agriculture in Africa. A total of 153 farmers were interviewed in both study areas using well structure questionnaire. The study describes the socioeconomic characteristics of farmers using descriptive statistics and thereafter the perception of Bako Tibe and Abeokuta farmers to climate change and variability was examined using Likert type scale. The binary logistics regression was later used to ascertain the effect of socioeconomic characteristics on perception of the farmers in both study areas. The farmers in both study areas believed that there have been changes in the amount of rainfall and temperature in the past thirty years. The farmers in Bako agreed that there have been increased temperature and decreased rainfall, contrary to the farmer's perception in Abeokuta. The binary logistic regression results showed that socioeconomic characteristics of farmers in Bako Tibe, have no effect on the perception of farmers on climate change and variability. However, in Abeokuta, age, land ownership, and distance to market had an effect on the perception on the farmers on climate change and variability. The adaptation strategies to climate change and variability commonly used by Bako Tibe farmers was, improved seed (drought resistance) adaptation method, while most farmers in Abeokuta used soil moisture conservation adaptation method. The study recommends that government and Non-Governmental Organization of both countries should promote more adaptation and mitigation
\end{abstract}


practices to climate change and variability through policy interventions to help curb the impact of climate change and variability to agriculture.

\section{Keywords}

Climate change \& Variability, Perception, Adaptation, Bako Tibe and Abeokuta

\section{Introduction}

Climate change and variability have adverse effects on economic development, and the effects are felt more in the rural economy, where there is high dependency on agriculture as source of livelihood. Climate change can be defined as statistically significant variations in climate that persisted for an extended period, typically decades or longer [1]. Climate variability on the other hand can be defined as natural climate fluctuations, including changes of mean state and varying occurrence of extremes [2]. Climate change and variability has been one of the leading global concerns, as it poses threat to man and its environment. One of such threats is its effect on agricultural production, which without adequate mitigation and adaptation strategies to climate change and variability could lead to food insecurity. The effects on agricultural activities are significant in Africa due to high dependency on rain-fed agriculture, and also large dependence on agricultural practice for livelihoods [3]. Ethiopia and Nigeria had experienced the impact of climate change \& variability, and there have been extreme climate (drought and flooding) in both countries. Also, there is high dependency on agriculture in both countries, agriculture production is a key sector in the Gross Domestic Product (GDP) of both countries, as it contributes $43 \%$ to Gross Domestic Product (GDP), [4], 90\% of export earnings and $80 \%$ of employment in Ethiopia, [5] while in Nigeria, agriculture contributes about $24 \%$ to the GDP of the economy [6]. Hence, the knowledge of the impact of climate change and variability is important for farmers in both countries, because climate extremes have an adverse effect on food production, so the knowledge of the impacts can help farmers develop adaptation strategies to curb food insecurity. One of the ways to keep a check on the impact of climate change and variability on agriculture production is understanding farmers' perception to climate change and variability. The perception of farmers to climate change and variability is important in mitigation and adaptation processes, because without the farmers perceiving climate change and variability, it will be difficult to plan adequate mitigation and adaptation strategies. Adaptation to climate change and variability refers to adjustment in natural or human systems in response to actual or expected climatic stimuli or their effects, which moderates harm or exploits beneficial opportunities [7]. There is a need to know more about how farmers perceive climate and how they respond, in both the short- and long-term, to variable climate conditions, including the magnitude and frequency of extreme condi- 
tions [8]. The knowledge of farmer's perception to climate change and variability is a guide to formulating adaptation policies to help curb the negative impact of climate change and variability.

Previous studies had tried to evaluate farmers' perception to climate change and variability by comparing farmer's perception with climate data. [9] compared farmers' perception of climate change and variability with historical climate data in the Upper East Region of Ghana, and the study showed that $71 \%$ of respondents perceived an increase in temperature which matches with the climatological evidence. Also, [10] compared farmers' perceptions in Southwestern Nigeria with historical meteorological data, in order to assess the way farmers' observations, mirror the climatic trends. The results show that about $67 \%$ of farmers who participated had observed recent changes in climate and perceptions of rural farmers on climate change and variability are consistent with the climatic trend analysis. However, [11] analysed the perception and adaptation to climate change in the Nile basin of Ethiopia using Heckman probit model to analyse the two-step process of adaptation to climate change, which initially requires farmer's perception that climate is changing and then responding to changes through adaptation. The result showed that majority of the farmers interviewed claimed that they have perceived at least one change in climatic attributes, some of the farmers who perceived climate change did not respond by taking adaptation measures. The present study tries to compare farmers' perception to climate change and variability in Ethiopia and Nigeria, using Bako Tibe, Ethiopia and Abeokuta, Nigeria, because study areas have similar farming practice as maize (Zea mays) is widely grown in both study locations and they both have relatively similar climate. The comparative evaluation was done, looking at the similarities and differences in farmer's perception and adaptation to climate change and variability in both study areas. The knowledge of farmer's perceptions to climate change and variability as well as their adaptation strategies in Bako Tibe and Abeokuta can help ascertain to a large extent, farmers' perception and adaptation strategies to climate change and variability in Africa and will also give empirical evidence of climate change and variability in Africa.

\section{Material and Methods}

\subsection{Study Area}

The study was conducted in Bako Tibe, Southern, Ethiopia and Abeokuta, South western Nigeria. Bako Tibe is located at $9^{\circ} 08^{\prime} \mathrm{N}$ and $37^{\circ} 03^{\prime} \mathrm{E}$ with a land mass of $644.69 \mathrm{Km}^{2}$ and an elevation of 1586 meters, while Abeokuta is located at $7^{\circ} 9^{\prime} 39^{\prime \prime} \mathrm{N}^{\circ} 20^{\prime} 54^{\prime \prime} \mathrm{E}$, with a land mass of $879 \mathrm{~km}^{2}$ and an elevation of 66 meters above sea level. [12] census reported a total population of 123,031 in Bako Tibe, while [13], reported a total population of 449,088 in Abeokuta. The long term mean annual rainfall for Bako area is $1244-1260 \mathrm{~mm}$ [14]. About 70\% and 80\% of the mean annual rainfall is received from June to September [15]. Bako Tibe sites have a mean maximum temperature of $28^{\circ} \mathrm{C}$ and a mean minimum tem- 
perature of $14.8^{\circ} \mathrm{C}-15^{\circ} \mathrm{C}$ [16] [17], while the long term mean annual rainfall for Abeokuta area is $1027-1900 \mathrm{~mm}$. About $70 \%$ and $80 \%$ of the mean annual rainfall is received from April to September. Abeokuta has a mean maximum temperature of $31^{\circ} \mathrm{C}$ and a mean minimum temperature of $25^{\circ} \mathrm{C}$.

\subsection{Sampling and Data Collection}

Data were collected from 153 farmers; 98 farmers in Bako Tibe and 55 farmers in Abeokuta. In each study areas a total of 100 questionnaire were distributed, but only 98 and 55 were valid in Bako Tibe and Abeokuta respectively. The sample size was more in Bako Tibe because the farmers were more readily disposed during the data collection, due to the incentive-based approach used for the farmers in Bako Tibe, unlike in Abeokuta, where the approach was not applied because it is not a common practice. Data were collected from both study areas through a multistage sampling procedure in February 2017 to May 2017. At the first stage, two sample locations (Bako Tibe and Abeokuta) were purposively selected from Ethiopia and Nigeria based on their agricultural production. Also, Bako Tibe has a relatively similar climate to Abeokuta, when compared with other states in Nigeria, and most farmers in both study areas were maize farmers. In the second stage farmers were randomly selected and interviewed from the sample locations using well-structured questionnaire.

\subsection{Data Analysis}

The socioeconomic characteristics (age, gender, marital status, level of education, household size, household head, access to credit, benefited from extension services, market distance, membership to cooperatives, farming experience, farm size, land ownership and training programme attended) was analysed using descriptive statistics. Likert scale type model was used to analyse the perception of farmers in both study areas. The farmers were asked if they had observed any changes: in the amount of temperature and rainfall in the past thirty years; if there had been increase in the amount of temperature and rainfall in the past thirty years; decrease in the amount of temperature and rainfall in the past 30 years; delay in the onset of rainfall in the past 30 years; weather extreme in the past 30 years, and any increase in yield in the past 30 years. Thereafter binary logistic model was used to determine the effect of the socioeconomic characteristics on the farmer's perception. The dependent variable was a dummy (Perceived change $=1$. Non-perceived $=0$ ), while the socioeconomic characteristics; age, sex, marital status, educational level, House Hold size, Household head, extension services, market distances, farm experience, member to cooperative society, access to credit, ownership of land, farm size, and climate related training programme attended, were the independent variables. The logistic regression model is specified as:

$$
P_{i}=F\left(\alpha+\beta X_{i}\right)=1 / 1 \mathrm{e}^{-\left(\alpha+\beta X_{i}\right)}
$$

where $i$ denotes the $i^{\text {th }}$ observation in the sample; $P_{i}$ is the probability that an 
individual will make a certain choice given $X_{\dot{p}}$ e is the base of natural logarithms and approximately equal to $2.718 ; X_{i}$ is a vector of exogenous; variables $\alpha$ and $\beta$ are parameters of the model, $\beta_{1}, \beta_{2} \cdots, \beta_{n}$ are the coefficients associated with each explanatory variables $X_{1}, X_{2}, \cdots, X_{n}$. The above function can be rewritten as:

$$
\log \frac{P_{i}}{1-P_{i}}=\beta_{0}+\beta_{1} X_{1}+\beta_{2} X_{2} \cdots \beta_{n} X_{n}
$$

where $i$ denote the $I^{\text {th }}$ observation in the sample and $P_{i}$ is the predicted probability of farmers' perception which is coded as a dummy variable with the value of 1 when a farmer has a good perception of the climate change and 0 otherwise (1 $\left.-P_{i}\right) . \beta_{0}$ is the intercept term, and $\beta_{1}, \beta_{2}$, and $\beta_{n}$ are the coefficients associated with each explanatory variable $X_{1}, X_{2}$ and $X_{n}+$.

\section{Results and Discussion}

The socioeconomic characteristics of the farmers in the study areas showed that $87 \%$ of farmers in Bako Tibe and $76 \%$ in Abeokuta were male (Table A1). The average age of the farmers in Bako Tibe was 45 years and 55 years in Abeokuta. Also, most of the farmers in both study areas were married, as $82 \%$ and $80 \%$ of farmers in Bako Tibe and Abeokuta were married. In Bako, 50\% of the farmer did not attain any formal education, $46 \%$ attained primary education, $1 \%$ attained secondary education, while $3 \%$ attained tertiary education. This is contrary to the level of education in Abeokuta, where only $2 \%$ of the farmer did not attain any formal education, $25 \%$ attained primary education, $40 \%$ attained secondary education, and $33 \%$ attained tertiary education. The results of the level of education from both study areas showed that the farmers in Abeokuta were more educated than the farmers in Bako. This could be due to the fact that in Bako Tibe, people go into farming at a relatively younger age, when compared to the average age in Abeokuta (As indicated above the average age of farmers in Bako Tibe was 45 years, while that of Abeokuta was 55 years), so they might see no need for education, when they can already earn a living from agriculture. Also, [18] estimates the adult literacy rate as 56.9 percent, and that of Ethiopia was $49 \%$ [19], which showed that Nigeria has a more educated population than Ethiopia.

The average household size in both study areas was six (6) ranging from 2 12. The household heads in both study areas were dominated by male, with a gender difference of $86 \%$ (Male-93\%: Female-7\%) in Bako Tibe and 52\% (Male: 76\%: Female-26\%) in Abeokuta. Though male predominated among the farmers in both areas, the gender imbalance was more among Bako Tibe farmers. The gender imbalance in both study areas may be as a result of male having more access to land and other productive resources than female in Africa. In Bako Tibe, $100 \%$ of the farmers interviewed lacked access to credit, while $80 \%$ of the farmers interviewed in Abeokuta had access to credit. This may be as a result of some of the farmer's intervention fund released by the Central Bank of Nigeria, 
such as Anchor Borrower's Programme, Agricultural Credit Guarantee Scheme Fund (ACGSF), Nigeria Incentive-Based Risk Sharing System for Agricultural Lending (NIRSAL) and Commercial Agriculture Credit Scheme (CACS). Also, in Bako Tibe, only $5 \%$ of the farmers interviewed belonged to a cooperative society, unlike in Abeokuta where $76 \%$ of the farmers interviewed belonged to a cooperative society. Extension services were not very well explored among the farmers interviewed in Bako Tibe, as only about $5 \%$ of the farmers had benefitted from extension services, while in Abeokuta, $95 \%$ of the farmers interviewed had benefitted from agriculture extension services. None of the farmers interviewed in Bako agreed to have attended training programme on climate change and variability, while $64 \%$ of the farmers in Abeokuta have benefited from training programme in climate change and variability. The average land size used by the farmers in Bako Tibe was 3 hectares, and most of the land was owned by the government, while the average land size used by farmers in Abeokuta was 10 hectares, and were mostly owned by the community and individuals. Though the land used by the farmers interviewed in Bako Tibe for farming was mostly owned by the government, individuals have right to farm on the land. The 1975 land reform in Ethiopia was designed to improve agriculture, create employment, improve livelihood and increase rural income. It, provided 10 ha of land as maximum a family can possess, there is prohibition on transfer-of-use right by sale, exchange, succession, mortgage or lease [20]. In Nigeria, the land use act in 1978, handed the lands in the urban to governors of state, who has the power to revoke land in case of breach of contract, they can grant statutory right of occupancy to any person or organization for agricultural purposes, residential and other purposes, while the local government, grants customary right of occupancy to any person or organization for agricultural purposes, residential and other purposes with the provision that grants of land for agricultural or grazing purposes should not exceed 500 or 5000 hectares respectively, without the consent of the state governor (Land use act 1978). The farmers in Bako had an average farming experience of 20 years, while the farmers in Abeokuta had a farming experience of about 27 years.

The perception of farmers on climate change and variability were ranked using weighted mean $(\mathrm{x})$. The mean score of respondents was based on the 5-point Likert rating scale with a cutoff point of 3 . The mean scores below 3 were ranked as within the range of disagree; while those above 3 were ranked as within the range of agree. The result from the Likert scale type analysis showed that farmers in both study area believed that there have been changes in the amount of rainfall and temperature in the past 30 years, especially in irregularity of rainfall and weather extremes. The farmers in Bako Tibe agree that there have been increased temperature at an average of 3.6 on the Likert type scale and decreased in rainfall at an average of 3.3., which had also affected their agricultural output and the revenue. Contrastingly, though the farmers in Abeokuta agreed to increase in temperature at 3.1 on the Likert type scale, most of the farmers in Abeokuta, do not agree that there have been decreases in rainfall at an average of 
2.2 on the Likert type scale. The farmers in both study areas agreed that there have been weather extremes in the past thirty years. Also, the farmers in Abeokuta agreed that there have been delay in the onset of rainfall, while Bako farmers disagreed to delay in the onset of rainfall.

The result of the binary logistic regression for the effect of socioeconomic characteristics on the perception of farmers in Bako Tibe showed that there was a positive correlation between the perception of farmers and some of the socioeconomic characteristics, such as sex, age, marital status, level of education, distance to market and membership to cooperatives. However, there was a negative correlation between the perception of farmers and Household size, farming experience, land ownership and land size. The result also gave an $\mathrm{R}$ squared of 0.33 and none of the socioeconomic characteristics of farmers in Bako Tibe was significant, which implies that the socioeconomic characteristics examined do not have an effect on the perception of the farmers in Bako Tibe, Ethiopia. The logistic regression for Abeokuta farmers was also performed to ascertain the effect of socioeconomic characteristics on perception of maize farmers on climate variability in Abeokuta, Nigeria. The model showed an R squared of 0.66 , and that marital status, level of education, membership to cooperatives, farming experience, land ownership and land size had a positive correlation with the dependent variable, while sex, age, household size, distance to market, access to credit, and benefit from extension services had a negative correlation. Land ownership, age and distance to market were significant at 0.01, 0.07 and 0.02 respectively, which implies that land ownership, age and distance to market had an effect on the perception to climate change and variability of the maize farmers in Abeokuta.

\section{Adaptation Strategies for Farmers in Both Study Areas}

The adaptation strategies examined in this study include; diversification, irrigation method, improved seed, altering fertilizer rate, making wider use of technologies to "harvest" water and conserve soil moisture, use of climate forecasting to reduce production risk, modification of grazing practice, shifting to species or areas more productive under new climatic conditions, and forest conservation (Table A2). The result showed that improved seed, making wider use of technologies to "harvest" water \& conserve soil moisture and modification of grazing practice, were the used more in Bako farmers as an adaptation strategy. While, altering fertilizer application, diversification and shifting to species or areas more productive under new climatic conditions, were used more by maize farmers in Abeokuta.

The farmers in both study areas used diversification method as an adaptation strategy, $88.78 \%$ and $74.55 \%$ of the farmers in Bako Tibe and Abeokuta respectively, used diversification as an adaptation strategy to climate variability and change. Also, 63.27\% and 3.6\% of maize farmers in Bako Tibe and Abeokuta respectively, used irrigation method as an adaptation strategy. Improved seed 
(Seeds with high water use efficiency and drought tolerant seed) was used by $92.86 \%$ of the farmers in Bako Tibe and $40 \%$ of farmers in Abeokuta as an adaptation strategy. The maize farmers also practice alteration of fertilizer rate as an adaptation strategy as $58.16 \%$ and $90.90 \%$ of maize farmers in Bako Tibe and Abeokuta respectively used alteration of fertilizer rate method. Also, $91.8 \%$ in Bako Tibe and $100 \%$ in Abeokuta used various methods to harvest water and practiced soil conservation method. Climate forecasting method was also used by $25.51 \%$ of maize farmers in Bako Tibe and $1.81 \%$ of maize farmers in Abeokuta as an adaptation strategy to reduce production risk. Modification of grazing practice was also used by $92.86 \%$ of maize farmers in Bako Tibe and $43.6 \%$ of maize farmers in Abeokuta, as an adaptation strategy. None (0\%) of the farmers in Bako Tibe and 54.54\% in Abeokuta used shifting to resilient species or shifting to more productive areas under new climatic conditions. Lastly, 9.18\% and $1.81 \%$ of farmers in Bako Tibe and Abeokuta respectively, used forest conservation methods as an adaptation strategy to climate variability.

A further description of the adaptation strategies using pie chart is shown in Figure 1, which showed that improved seed, modification of grazing practices and making wider use of technologies to "harvest" water \& conserve soil moisture were used mostly by the farmers interviewed in Bako Tibe. While in Abeokuta, altering of fertilizer rate and making wider use of technologies to "harvest" water \& conserve soil moisture were used mostly by the farmers.
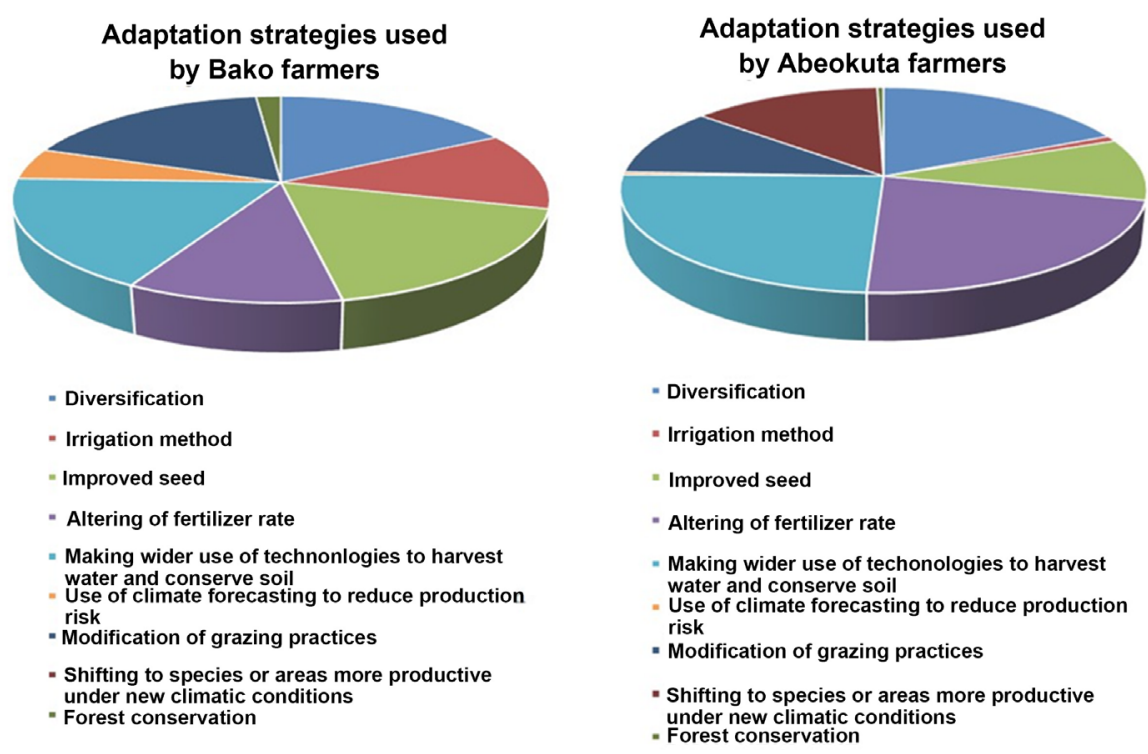

Figure 1. Adaptation strategies used by farmers in both study areas. Source: Field survey, 2017.

The farmers in both study areas used extensively "making wider use of technologies to 'harvest' water \& conserve soil moisture" as an adaption strategy. This might be due to high dependency on rain by farmers in both study areas and less dependency on irrigation. As seen in Figure 1, 62\% of the farmers in 
Bako Tibe used irrigation method as an adaptation strategy to climate change and variability, while only $3.6 \%$ of the farmers used irrigation method in Abeokuta., this could be as a result of a higher mean annual rainfall in Abeokuta than Bako Tibe, so the farmers in Abeokuta are more likely to access rainwater than Bako Tibe.

\section{Conclusion}

Most of the farmers in the study areas have perceived climate change and variability, and have also adopted various adaptation strategies to climate change and variability. The binary logistics regression showed that land ownership, age and distance to market had an effect on the perception of farmers in Abeokuta, while in Bako Tibe, the socioeconomic characteristics of the farmers have no effect on their perception. The adaptation strategies used for the study were: diversification; irrigation method; improved seed; altering fertilizer rate; making wider use of technologies to "harvest" water and conserve soil moisture; forest conservation; use of climate forecasting to reduce production risk; modification of grazing practice and lastly, shifting to species or areas more productive under new climatic conditions. Though a greater percentage of farmers in both study areas used water harvest and soil conservation method, improved seed method was mostly used the farmers in Bako Tibe, while water harvest \& soil conservation was mostly used in Abeokuta. The farmers in both study areas used combinations of adaptation strategy to curb the effect of climate change and variability on their farm output. Climate change and variability can have adverse effect on the quality and quantity of agriculture products if proper adaptation and mitigation strategies are not put in place. This study showed that farmers in both study areas have not only perceived climate change and variability, but had also understood the impact it has on agriculture, and so are taking adaptation strategies. Government and Non-Governmental Organization of both countries should also promote more adaptation and mitigation practices to climate change and variability through policy interventions to assist farmers in curbing the impact of climate change and variability in agriculture.

\section{Conflicts of Interest}

The authors declare no conflicts of interest regarding the publication of this paper.

\section{References}

[1] Intergovernmental Panel on Climate Change (IPCC) (Core Writing Team, Pachauri, R.K. and Reisinger, A., Eds.) (2007) Climate Change 2007: Synthesis Report. Contribution of Working Groups I, II and III to the Fourth Assessment Report of the Intergovernmental Panel on Climate Change. IPCC, Geneva.

[2] FAO (2012) Special Event on Impact of Climate Change, Pests and Diseases on Food Security and Poverty Reduction, Background Document for 31st Session of IDS WORKING PAPER the Committee on World Food Security. Rome, 23-26 May 2005.

[3] Yohannes, H. (2016) A Review on Relationship between Climate Change and Agri- 
culture. Journal of Earth Science and Climatic Change, 7, 335.

https://doi.org/10.4172/2157-7617.1000335

[4] Tirado, R. and Cotter, J. (2010) Ecological Farming: Drought Resistant Agriculture. University of Exter, UK. Amsterdam, the Netherlands: Greenpeace International Research Labratories.

http://www.greenpeace.org/international/en/publications/reports/Ecological-farmin g-Drought-resistant-agriculture/

[5] Ministry of Finance and Economic Development (MoFed) (2010) Growth and Transformation Plan 2010/11. Mimeo, Addis Ababa.

[6] Central Bank of Nigeria (2016) Statistical Bulletin.

[7] Intergovermental Panel on Climate Change (IPCC) (2001) Climate Change 2001: Impacts, Adaptation and Vulnerability, Summary for Policymakers, Working Group II: Impact, Adaptation and Vulnerability.

[8] Smit, B., Burton, I., Klein, R.B. and Stree, R. (1999) The Science of Adaptation: A Framework for Assessment. Mitigation and Adaptation Strategies for Global Change, 4, 199-213. https://doi.org/10.1023/A:1009652531101

[9] Amadou, M.L., Villamor, G.B., Attua, E.M. and Traoré, S.B. (2015) Comparing Farmers' Perception of Climate Change and Variability with Historical Climate Data in the Upper East Region of Ghana. Ghana Journal of Geography, 7, No. 1.

[10] Ayanlade, A., Radeny, M. and Morton, J.F. (2017) Comparing Smallholder Farmers' Perception of Climate Change with Meteorological Data: A Case Study from Southwestern Nigeria. Weather and Climate Extremes, 15, 24-33. https://doi.org/10.1016/j.wace.2016.12.001

[11] Deressa, T.T. (2007) Measuring the Economic Impact of Climate Change on Ethiopian Agriculture: Ricardian Approach. Policy Research Working Paper; No. 4342. World Bank, Washington, DC. https://doi.org/10.1596/1813-9450-4342

[12] 2007 Population and Housing Census of Ethiopia: Results for Oromia Region, Vol. 1.

[13] National Population Commission (2006) Population Figures. NPC, Abuja (FCT).

[14] Negassa, W., Gebrekidan, H. and Friesen, D.K. (2005) Integrated Use of Farmyard Manure and NP Fertilizers for Maize on Farmer's Fields. Journal of Agriculture and Rural Development in the Tropics and Subtropics, 106, 131-141.

[15] Araya, A., Girma, A. and Getachew, F. (2015) Exploring Impacts of Climate Change on Maize Yield in Two Contrasting Agro-Ecologies of Ethiopia. Asian Journal of Applied Science and Engineering, 4, 27-37.

[16] Laike, S., Tilahun, K. and Hordofa, T. (2006) Crop Coefficient of Haricot Bean at Melkasa, Central Rift Valley of Ethiopia. Journal of Agriculture and Rural Development in the Tropics and Subtropics, 107, 33-40.

[17] Shenkute A., Tesfaye, K. and Abegaz, F. (2013) Determination of Water Requirement and Crop Coefficient for Sorghum (Sorghum bicolor L.) at Melkasa, Ethiopia. STAR Journal, 2, 16-24.

[18] National Bureau of Statistics (2010) The National Literacy Survey, 2010. http://www.nigerianstat.gov.ng

[19] UNESCO Institute for Statistics (UIS) (2009) The Next Generation of Literacy Statistics; Implementing the Literacy Assessment and Monitoring Programme (LAMP). UIS Technical paper No. 1 Montreal: UIS. http://www.uis.unesco.org/Library/Documents/Tech1-eng.pdf

[20] Nega, B., Adenew, B. and Gebre Sellasie, S. (2003) Current Land Policy Issues in Ethiopia. Land Reform, Land Settlement and Cooperative, Food and Agriculture Organization (FAO), 2003 (3). 


\section{Appendix}

Table A1. Socioeconomics characteristics of farmers in the study area.

\begin{tabular}{|c|c|c|c|c|c|c|c|}
\hline \multirow{2}{*}{$\begin{array}{l}\text { SOCIOECONOMIC } \\
\text { CHARACTERISTICS }\end{array}$} & \multirow{2}{*}{ UNIT } & \multicolumn{3}{|c|}{ BAKO TIBE, ETHIOPIA } & \multicolumn{3}{|c|}{ ABEOKUTA, NIGERIA } \\
\hline & & Frequency & Percentage & Standard Dev. & Frequency & Percentage & Standard Dev. \\
\hline MEAN AGE & Years & 45 & - & 8.66 & 56 & - & 14.4 \\
\hline \multirow[t]{2}{*}{ GENDER } & Male & 85 & 87 & & 42 & 76 & \\
\hline & Female & 13 & 13 & & 13 & 24 & \\
\hline \multirow[t]{4}{*}{ MARITAL STATUS } & Single & 3 & 3 & & 10 & 18 & \\
\hline & Married & 80 & 82 & & 44 & 80 & \\
\hline & Divorced/separated & 4 & 4 & & 1 & 2 & \\
\hline & Widow/widower & 11 & 11 & & 0 & 0 & \\
\hline \multirow[t]{4}{*}{ LEVEL OF EDUCATION } & No formal education & 49 & 50 & & 1 & 2 & \\
\hline & Primary & 45 & 46 & & 14 & 25 & \\
\hline & Secondary & 1 & 1 & & 22 & 40 & \\
\hline & Tertiary & 3 & 3 & & 18 & 33 & \\
\hline $\begin{array}{l}\text { MEAN HOUSEHOLD } \\
\text { SIZE }\end{array}$ & No. of Persons & 6.21 & - & 2.48 & 6.1 & - & 1.9 \\
\hline \multirow[t]{2}{*}{ HOUSEHOLD HEAD } & Male & 91 & 93 & & 42 & 76 & \\
\hline & Female & 7 & 7 & & 13 & 24 & \\
\hline \multirow[t]{2}{*}{ ACCESS TO CREDIT } & Have access to credit & 0 & 0 & & 44 & 80 & \\
\hline & $\begin{array}{l}\text { Does not have access } \\
\text { to credit }\end{array}$ & 98 & 100 & & 11 & 20 & \\
\hline \multirow[t]{2}{*}{$\begin{array}{c}\text { BENEFITED FROM } \\
\text { EXTENSION SERVICES }\end{array}$} & Have benefitted & 5 & 5 & & 37 & 67 & \\
\hline & Have not benefitted & 93 & 95 & & 18 & 33 & \\
\hline $\begin{array}{l}\text { MEAN MARKET } \\
\text { DISTANCE }\end{array}$ & Kilometers & 6.5 & - & 2.96 & 5.2 & - & 2.1 \\
\hline \multirow[t]{2}{*}{$\begin{array}{l}\text { MEMBER OF } \\
\text { COOPERATIVE }\end{array}$} & Belongs to cooperative & 5 & 5 & & 42 & 76 & \\
\hline & $\begin{array}{l}\text { Does not belong to } \\
\text { cooperative }\end{array}$ & 93 & 95 & & 13 & 24 & \\
\hline $\begin{array}{l}\text { MEAN FARMING } \\
\text { EXPERIENCE }\end{array}$ & Years & 20.1 & - & 8.0 & 26.6 & - & 15.7 \\
\hline MEAN FARM SIZE & Hectares & 2.9 & - & 1.87 & 10.4 & - & 6.7 \\
\hline \multirow[t]{3}{*}{ OWNERSHIP OF LAND } & Individual & 0 & 0 & & 48 & 87 & \\
\hline & Government & 98 & 100 & & 7 & 13 & \\
\hline & Community & 0 & 0 & & 0 & 0 & \\
\hline \multirow{3}{*}{$\begin{array}{c}\text { TRAINING } \\
\text { PROGRAMME ON } \\
\text { CLIMATE CHANGE }\end{array}$} & & & & & & & \\
\hline & Attended Training & 0 & 0 & & 20 & 36 & \\
\hline & $\begin{array}{l}\text { Not Attended } \\
\text { Training }\end{array}$ & 98 & 100 & & 35 & 64 & \\
\hline
\end{tabular}


Table A2. Adaptation strategies of maize farmers in the study areas.

\begin{tabular}{|c|c|c|c|c|c|c|}
\hline \multirow[b]{2}{*}{ Adaptation Strategies } & \multicolumn{4}{|c|}{ Bako } & \multicolumn{2}{|c|}{ Abeokuta } \\
\hline & $\begin{array}{c}\text { No. of } \\
\text { Farmers }\end{array}$ & $\%$ of Farmers & $\begin{array}{l}\text { Total no. of } \\
\text { farmers }\end{array}$ & $\begin{array}{c}\text { No. of } \\
\text { Farmers }\end{array}$ & $\%$ of Farmers & $\begin{array}{l}\text { Total no. of } \\
\text { farmers }\end{array}$ \\
\hline Diversification & 87 & 88.78 & 98 & 41 & 74.55 & 55 \\
\hline Irrigation method & 62 & 63.27 & 98 & 2 & 3.6 & 55 \\
\hline Improved seed & 91 & 92.86 & 98 & 22 & 40.0 & 55 \\
\hline Altering fertilizer rate & 57 & 58.16 & 98 & 50 & 90.90 & 55 \\
\hline $\begin{array}{l}\text { Making wider use of technologies to } \\
\text { "harvest" water and conserve soil moisture }\end{array}$ & 90 & 91.84 & 98 & 55 & 100 & 55 \\
\hline $\begin{array}{l}\text { Use of climate forecasting to reduce } \\
\text { production risk }\end{array}$ & 25 & 25.51 & 98 & 1 & 1.81 & 55 \\
\hline Modification of grazing practice & 91 & 92.86 & 98 & 24 & 43.6 & 55 \\
\hline $\begin{array}{l}\text { Shifting to species or areas more } \\
\text { productive under new climatic conditions }\end{array}$ & 0 & 0 & 98 & 30 & 54.54 & 55 \\
\hline Forest conservation & 9 & 9.18 & 98 & 1 & 1.81 & 55 \\
\hline
\end{tabular}

Source: Field survey, 2017.

Perception of the maize farmers in both study areas.

\begin{tabular}{|c|c|c|c|c|c|}
\hline & \multirow{2}{*}{ Farmers Perception } & \multicolumn{2}{|c|}{ Bako, Ethiopia } & \multicolumn{2}{|c|}{ Abeokuta, Nigeria } \\
\hline & & Mean & Standard Dev. & Mean & Standard Dev. \\
\hline 1) & $\begin{array}{l}\text { There have been changes in the amount } \\
\text { of temperature in the past } 30 \text { years }\end{array}$ & 3.8 & 1.0 & 3.9 & 0.3 \\
\hline 2) & $\begin{array}{l}\text { There have been changes in the amount } \\
\text { of rainfall in the past } 30 \text { years }\end{array}$ & 3.9 & 1.1 & 3.9 & 0.3 \\
\hline 3) & $\begin{array}{l}\text { There have been increase in the amount } \\
\text { of rainfall in the past thirty years }\end{array}$ & 1.7 & 0.9 & 2.7 & 1.0 \\
\hline 4) & $\begin{array}{l}\text { There have been increase in the amount } \\
\text { of temperature in the last } 30 \text { years }\end{array}$ & 3.6 & 1.2 & 3.1 & 0.6 \\
\hline 5) & $\begin{array}{l}\text { There have been decrease in the amount } \\
\text { of rainfall in the past } 30 \text { years }\end{array}$ & 3.3 & 1.2 & 2.2 & 1.3 \\
\hline 6) & $\begin{array}{l}\text { There have been decrease in the amount } \\
\text { of temperature in the past } 30 \text { years }\end{array}$ & 1.6 & 1.2 & 1.0 & 0.9 \\
\hline 7) & $\begin{array}{l}\text { There have been delay in the onset of } \\
\text { rainfall in the past } 30 \text { years }\end{array}$ & 1.5 & 1.1 & 3.5 & 0.7 \\
\hline 8) & $\begin{array}{l}\text { There have been weather extreme in the } \\
\text { past } 30 \text { years }\end{array}$ & 4.0 & 1.0 & 3.4 & 0.7 \\
\hline
\end{tabular}

Binary logistic regression model Summary Bako.

$\begin{array}{cccc}\text { Step } & -2 \text { Log likelihood } & \text { Cox \& Snell R Square } & \text { Nagelkerke R Square } \\ 1 & 18.023^{\mathrm{a}} & 0.090 & 0.330\end{array}$


Binary logistic regression variables for Bako.

\begin{tabular}{cccccc}
\hline Independent variables & B & S.E. & df & Sig. & Exp(B) \\
Sex & +8.447 & 5.767 & 1 & 0.143 & 4660.053 \\
Age & +0.204 & 0.146 & 1 & 0.163 & 1.226 \\
Marital status & +2.030 & 1.666 & 1 & 0.223 & 7.611 \\
Level of education & +1.589 & 1.748 & 1 & 0.363 & 4.900 \\
Household size & -0.360 & 0.400 & 1 & 0.369 & 0.698 \\
Distance to market & +0.646 & 0.639 & 1 & 0.312 & 1.907 \\
Membership to cooperative & +13.987 & $16,595.725$ & 1 & 0.999 & $1,187,567.438$ \\
Farming experience & -0.202 & 0.199 & 1 & 0.310 & 0.817 \\
Land ownership & -3.847 & 5.073 & 1 & 0.448 & 0.021 \\
Land size & -0.603 & 0.489 & 1 & 0.218 & 0.547 \\
Constant & -8.504 & 9.136 & 1 & 0.352 & 0.000
\end{tabular}

Source: Field survey, 2017.

Binary logistic regression model Summary for Abeokuta.

\begin{tabular}{cccc}
\hline Step & -2 Log likelihood & Cox \& Snell R Square & Nagelkerke R Square \\
\hline 1 & $35.448^{\mathrm{a}}$ & 0.493 & 0.669 \\
\hline
\end{tabular}

Binary logistic variables for Abeokuta.

\begin{tabular}{|c|c|c|c|c|c|}
\hline Independent variables & B & S.E. & df & Sig. & $\operatorname{Exp}(B)$ \\
\hline Sex & -2.236 & 1.475 & 1 & 0.129 & 0.107 \\
\hline Age & -0.137 & 0.076 & 1 & ${ }^{\star} 0.072$ & 0.872 \\
\hline Marital status & 5.764 & 3.572 & 1 & 0.107 & 318.745 \\
\hline Level of education & 0.019 & 0.117 & 1 & 0.874 & 1.019 \\
\hline House hold size & -0.415 & 0.394 & 1 & 0.292 & 0.661 \\
\hline Distance to market & -0.783 & 0.328 & 1 & ${ }^{*} 0.017$ & 0.457 \\
\hline Access to credit & -25.033 & $23,813.346$ & 1 & 0.999 & 0.000 \\
\hline Benefited from ext. service & -0.290 & 1.136 & 1 & 0.798 & 0.748 \\
\hline Membership to cooperatives & 19.513 & $23,813.346$ & 1 & 0.999 & $297,993,644.958$ \\
\hline Farming experience & 0.094 & 0.067 & 1 & 0.159 & 1.099 \\
\hline Land ownership & 4.657 & 1.663 & 1 & ${ }^{*} 0.005$ & 105.348 \\
\hline Land size & 0.011 & 0.092 & 1 & 0.907 & 1.011 \\
\hline Constant & 4.974 & 4.128 & 1 & 0.228 & 144.675 \\
\hline
\end{tabular}

Source: Field survey, 2017. 